\title{
EFIKASI OXYTETRACYCLINE TERHADAP KESEHATAN IKAN LELE (Clarias sp.) YANG DIINFEKSI BAKTERI Edwardsiella tarda
}

\author{
Qurrota A'yunin $^{\mathrm{a}, *}$, Hartati Kartikaningsih ${ }^{\mathrm{b}}$, Sri Andayani ${ }^{\mathrm{c}}$, Mia Surantika D. ${ }^{\mathrm{c}}$, Fariedah, Fani ${ }^{\mathrm{c}}$, \\ Agoes Soeprijanto $^{\mathrm{a}}$, Nasrullah Bai A. ${ }^{\mathrm{c}}$ \\ ${ }^{a)}$ Bidang Bioteknologi Perikanan dan Kelautan,

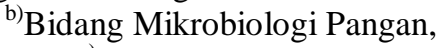 \\ ${ }^{\mathrm{c})}$ Bidang Akuakultur \\ Fakultas Perikanan dan Ilmu Kelautan, Universitas Brawijaya Jl. Veteran, Malang, Indonesia \\ *Koresponden penulis: qurrota_ayunin@ub.ac.id
}

\begin{abstract}
Abstrak
Edwardsiellosis adalah penyakit yang biasa menginfeksi ikan air tawar termasuk ikan lele (Clarias sp). Penyakit Edwardsiellosis disebabkan oleh infeksi bakteri Edwardsiella tarda dan dapat menyebabkan kematian masal pada ikan air tawar yang dibudidayakan. Penanggulangan penyakit pada ikan air tawar dapat menggunakan obat-obatan atau antibiotik yang tergolong aman dan penggunaannya sesuai aturan pemerintah. Penelitian ini bertujuan untuk mengetahui dosis oxytetracycline yang tepat sebagai obat ikan lele (Clarias sp.) yang terinfeksi bakteri Edwardsiella tarda melalui analisa histologi. Desain penelitian menggunakan Rancangan Acak Lengkap (RAL) dengan 3 perlakuan, 1 kontrol dan 3 kali ulangan pada tiap perlakuan. Ikan lele yang digunakan berukuran $\pm 25 \mathrm{~cm}$ dan dosis oxytetracycline yang digunakan yaitu 15, 30, dan 45 ppm. Hasil menunjukkan adanya kerusakan jaringan Nekrosis, Kongesti, Degenerasi Hialin, dan Deskuamasi Epitel Integumen pada ikan yang terinfeksi bakteri Edwardsiella tarda dengan scoring kerusakan terendah pada ikan yang diobati oxytetracycline dengan dosis 45 ppm. Hal ini mengindikasikan bahwa pemberian oxytetracycline berpengaruh terhadap histologi otot dan pemulihan kesehatan ikan.
\end{abstract}

Kata kunci: Edwardsiellosis, histologi, kesehatan ikan, pengobatan

\begin{abstract}
Edwardsielliosis is a disease that commonly infects freshwater fish including catfish (Clarias sp). Edwardsiellosis is caused by Edwardsiella tarda infection and causes mass mortality in catfish farming. Overcoming diseases in freshwater fish can use drugs or antibiotics that are classified as safe and their use is in accordance with government regulations. This study aims to determine the appropriate dosage of Oxytetracycline in catfish infected by E. tarda bacteria through histological analysis. The study design used Completely Randomized Design with 3 treatments, 1 control and 3 replications in each treatment. Catfish used were $\pm 25 \mathrm{~cm}$ in size and the dose of oxytetracycline used were 15, 30, and $45 \mathrm{ppm}$. The results showed tissue damage namely necrosis, congestion, Hyaline degeneration, Integument Desquamation, and haemorhage in fish infected with Edwardsiella tarda bacteria with the lowest damage at 45 ppm of oxytetracycline treatment. The results indicate that oxytetracycline has an effect on muscle histology and recovery of fish health.
\end{abstract}

Key words: Edwardsielliosis, fish health, histology, Medication

\section{Pendahuluan}

Ikan lele merupakan salah satu ikan air tawar. Ikan lele tergolong ikan omnivora yang mempunyai pertumbuhan cepat dan memiliki kemampuan toleransi terhadap parameter lingkungan dalam batas yang luas. Ikan lele adalah spesies ikan yang potensial untuk dibudidayakan [1]. Jenis ikan lele merupakan komoditas yang sangat rentan terhadap penyakit Edwardsiellosis yang disebabkan oleh bakteri Edwardsiella tarda [2].

Edwardsiella merupakan bakteri penyebab terjadinya penyakit bakterial 
sistemik Enteric Septicemia of Catfish (ESC) [3]. Edwardsiella tarda adalah agen penyebab penyakit yang kerap ditemukan menyebabkan kegagalan pada budidaya catfish di Indonesia [4]. Edwardsiellosis dapat ditularkan secara horizontal antara ikan sakit dan ikan sehat, dapat bertahan di dalam air dan lumpur sehingga air dan lumpur yang sudah bebas dari ikan sakit pun dapat menjadi karier dan menyebabkan penyakit pada ikan [5].

Pengamatan histopatologi dilakukan untuk memberikan gambaran perubahan jaringan yang terinfeksi penyakit. Diagnosa infeksi penyakit merupakan langkah awal yang perlu diterapkan, dalam penentuan penyakit. Pada proses diagnosa infeksi penyakit, terdapat beberapa hal yang perlu diperhatikan yaitu tanda-tanda klinis yang meliputi tingkah laku, ciri-ciri eksternal maupun internal serta perubahan patologi. Cara mengetahui perubahan patologi pada jaringan yang terinfeksi penyakit, perlu dilakukan pemeriksaan histopatologi.

Metode penanggulangan penyakit pada ikan air tawar adalah dengan penggunaan zat kimia atau antibiotika. Pada umumnya pembudidaya sering melakukan pemberian berbagai macam antibiotik seperti ampicillin, chloramphenicol, tetracycline dan disinfektan pada ikan. Antibiotik ini dipercaya oleh para pembudidaya dapat mengobati ikan yang terinfeksi bakteri. Penelitian ini bertujuan untuk mengetahui dosis oxytetracycline yang tepat sebagai obat ikan lele (Clarias sp.) yang terinfeksi bakteri Edwardsiella tarda melalui analisa histologi.

\section{Metode Penelitian}

Desain penelitian menggunakan Rancangan Acak Lengkap (RAL) dengan 3 perlakuan, 1 kontrol dan 3 kali ulangan pada tiap perlakuan. Ikan lele yang digunakan berukuran $\pm 25 \mathrm{~cm}$ dan dosis oxytetracycline yang digunakan yaitu 15,30 , dan 45 ppm. Penelitian ini dilaksanakan di Laboratorium Budidaya Ikan divisi Penyakit dan Kesehatan Ikan, Fakultas Perikanan dan Ilmu Kelautan, Laboratorium Mikrobiologi, Fakultas Kedokteran, Universitas Brawijaya, Malang dan Balai Karantina Ikan dan Pengendali Mutu (BKIPM) Kelas I, Juanda, Surabaya pada bulan Mei sampai dengan Juni 2018.

\section{Isolasi Bakteri}

Bakteri E. tarda diisolasi dari daerah budidaya ikan di Jawa Timur, Indonesia dan dibiakkan menggunakan media MIE dan MacConkey (MAC). Masing-masing koloni bakteri dikultur dalam medium cair TSB dan medium padat TSA, kemudian diinkubasi pada suhu $37^{\circ} \mathrm{C}$ selama $18-24$ jam. Pengamatan $\mathrm{LD}_{50}$ dilakukan untuk menemukan kepadatan yang cepat terinfeksi ke ikan lele. Kepadatan E. tarda adalah $10^{6}$ $\mathrm{CFU} / \mathrm{ml}, 10^{7} \mathrm{CFU} / \mathrm{ml}$ dan $10^{8} \mathrm{CFU} / \mathrm{ml}$. Langkah selanjutnya yaitu dilakukan pengamatan gejala klinis pada ikan yang disebabkan oleh infeksi $E$. tarda sehingga ikan menunjukkan perilaku pasif hingga $50 \%$ kematian pada ikan lele pada periode tertentu.

\section{Infeksi Bakteri}

Ikan lele diperoleh dari daerah Malang dengan ukuran $\pm 25 \mathrm{~cm}$. Setiap akuarium diisi dengan 10 ekor ikan lele. Infeksi E. tarda dilakukan dengan menggunakan metode imersi dalam media pemeliharaan dengan kepadatan bakteri $10^{7} \mathrm{CFU} / \mathrm{ml}$, kemudian dilakukan pengamatan gejala klinis pada ikan lele.

\section{Pengambilan Organ}

Pengambilan sampel organ ikan lele dilakukan pada 48 jam untuk sampel ikan yang terinfeksi $E$. tarda dan pada 96 jam atau 24 jam setelah pemberian antibiotik, kemudian dilakukan pembuatan preparat histopatologi. Jaringan diambil kemudidan direndam dalam 2 ml larutan NBF 10\% dan dibiarkan selama 24 jam. Setelah fiksasi, dilanjutkan dengan proses embedding dalam konsentrasi multilevel alkohol dan larutan xilol, dan ditanam dalam parafin. Semua proses ini dilakukan dengan prosesor jaringan. Blok-blok yang terbentuk dari proses embedding kemudian dipotong menggunakan mikrotom dengan ketebalan irisan $5 \mu$. Hasil potongan yang tipis dan menyerupai pita diletakkan di atas permukaan air di dalam waterbath $\left(40^{\circ} \mathrm{C}\right)$ sampai jaringan mengembang dengan baik. Jaringan kemudian diangkat menggunakan obyek glass dan dikeringkan menggunakan slide drying bench selama 10 menit. Objek kaca diatur dalam 
kotak pewarna kemudian dilakukan pewarnaan menggunakan Harri's Hematoksilin dan Eosin. Pengamatan histopatologi dilakukan menggunakan mikroskop.

\section{Analisis Histopatologi}

Hasil uji histopatologi otot pada ikan lele dianalisis menggunakan statistik skoring dengan metode semi kuantitatif untuk mengetahui tingkat kerusakan jaringan otot ikan lele yang telah diberi perlakuan. Metode semi-kuantitatif dilihat dari lima bidang pandang yang luas sehingga memperoleh hasil maksimal dalam tingkat kerusakan jaringan. Setiap bidang pandang diamati tingkat kerusakan jaringan dengan kriteria untuk nekrosis, vakuolisasi, edema dan hemoragi. Persentase kerusakan untuk setiap lapang pandang dihitung berdasarkan jumlah sel yang telah rusak.

\section{Pemberian Oxytetracycline}

Setelah infeksi, antibiotik oxytetracycline diberikan. Setelah 24 jam pengobatan dilakukan analisis histopatologi sampel otot setelah treatment.

\section{HaSil dan Pembahasan}

Dalam penelitian ini, kondisi otot ikan lele kontrol menunjukkan kondisi jaringan normal (dapat dilihat pada gambar 1), dengan tampilan struktur jaringan yang ketat/kompak. Posisi otot lurik dan otot polos juga muncul secara teratur tanpa kerusakan.

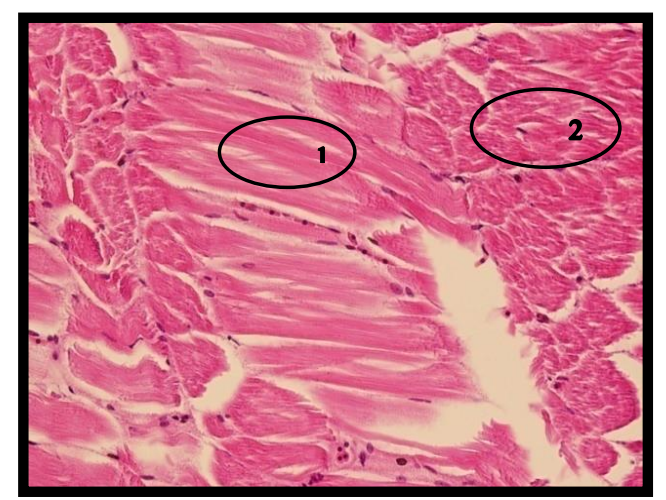

Gambar 1. Struktur jaringan otot normal pada ikan lele. (1) otot halus, (2) otot lurik. Perbesaran mikroskop 400x, potongan horizontal.
Hal ini berbeda dengan ilustrasi jaringan otot lele setelah infeksi bakteri $E$. tarda yang tampak adanya kerusakan jaringan termasuk nekrosis, vakuolisasi, edema dan hemoragi yang dapat dilihat pada gambar 2 dan 3.

Jumlah rata-rata kerusakan nekrosis pada jaringan otot lele di setiap perlakuan A, B, C dan kontrol adalah 3.200, 2.667, 2.300 dan 3.800. Rata-rata terendah diperoleh dalam C $(45 \mathrm{mg} / \mathrm{L})$, ini diduga karena dosis oxytetracycline dalam $\mathrm{C}$ diberikan untuk mengobati ikan lele yang telah terinfeksi oleh E. tarda.
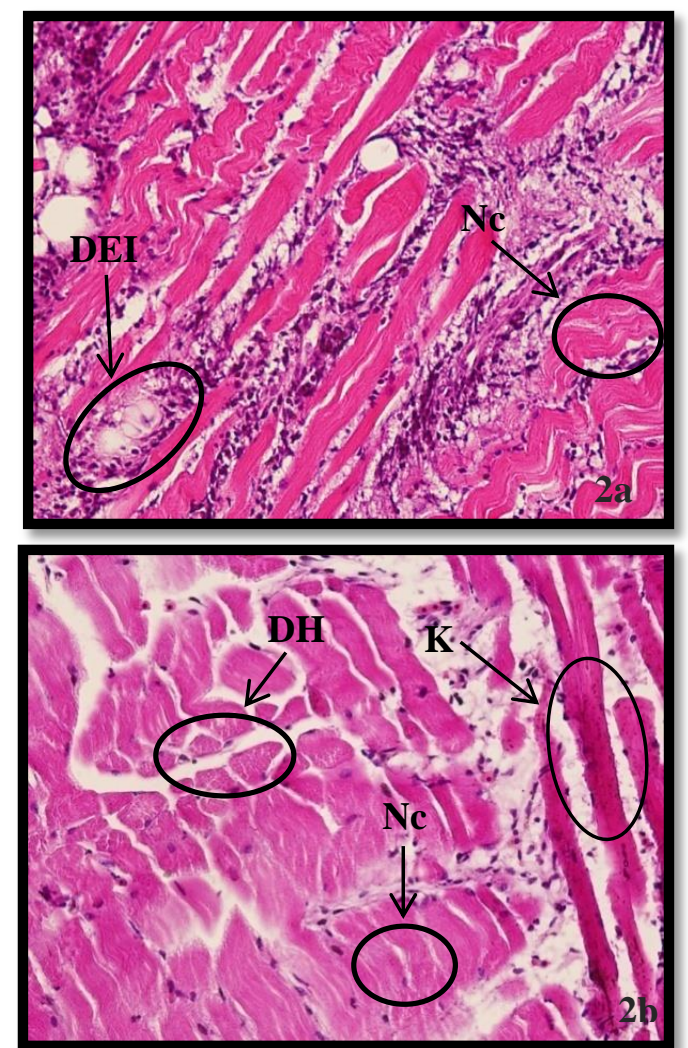

Gambar 2a dan 2b. Struktur Jaringan Otot Ikan Lele (Nc). Nekrosis, (K) Kongesti, (DH) Degenerasi Hialin, (DEI) Deskuamasi Epitel Integumen. Perbesaran mikroskop 400x. 


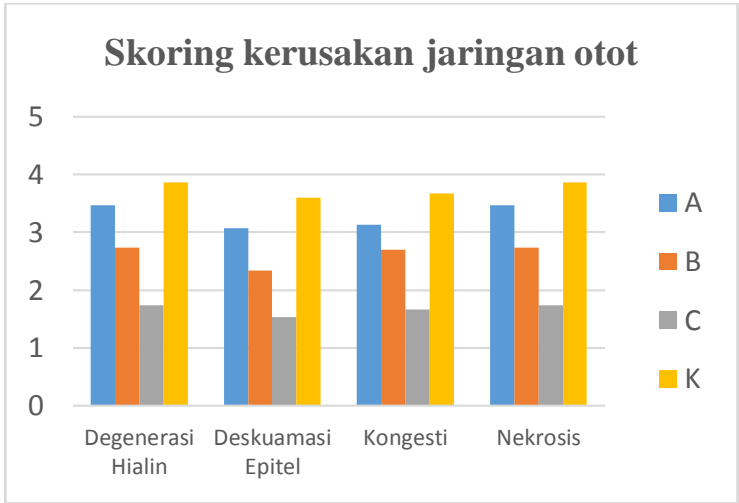

Gambar 3. Skoring kerusakan Jaringan Otot

Nekrosis adalah bentuk sel mati yang biasanya terjadi bersamaan dengan pecahnya membran plasma. Sel yang mengalami nekrosis dapat dikenali dari bentuk intinya yang mengecil (piknotik), membesar, kabur atau hilang (karyolisis) [2]. Karakteristik jaringan nekrotik, yang memiliki warna lebih pucat daripada warna normal, kehilangan daya rentang (jaringan menjadi rapuh dan mudah robek), atau memiliki konsistensi yang buruk atau pucat. Nekrosis sel disebabkan oleh agen biologis seperti virus, bakteri, jamur, dan parasit atau agen kimia serta gangguan pada antigen fagosit juga menurun.

Perbedaan penampang jaringan histopatologi otot yang berbeda pada tiap perlakuan bisa dikatakan karena pemberian dosis yang berbeda, pada nilai skoring menunjukkan bahwa perbedaan pemberian dosis yang berbeda mempengaruhi pemulihan jaringan otot ikan lele yang terinfeksi Edwardsiella tarda. Hal tersebut sesuai dengan pendapat [6], Oxytetracycline bersifat bakteriostatik dengan jalan menghambat sintesis protein. Sintesis protein berlangsung dalam beberapa tahap, salah satunya adalah tahap translasi. Translasi dibagi menjadi tiga tahap, yaitu inisiasi, elongasi, dan terminasi. Penyebab dari edema adalah meningkatnya tekanan hidrostatik intra vaskula menyebabkan perembesan cairan plasma darah keluar dan masuk ke dalam ruang interstisium. Kondisi tekanan hidrostatik sering ditemukan pembendungan pada vena (kongesti).

Berdasarkan hasil skoring kerusakan jaringan vakuolisasi dapat disimpulkan bahwa semakin tinggi dosis pengobatan maka semakin kecil kerusakan vakuolisasi pada histopatologi otot ikan lele (Clarias sp.).
Seperti yang dikemukakan oleh [7], bahwa dosis obat yang tinggi dapat menekan mekanisme pertahanan dan dosis yang terendah tidak efektif atau tidak cukup untuk mengobati ikan yang terinfeksi bakteri.

Vakuolisasi terjadi akibat kerusakan sel (nekrosis). Vakuolisasi adalah kerusakan pada hepatosit yaitu inti sel dan sitoplasma yang sudah tidak tampak lagi [8]. Vakuolisis mempunyai ciri-ciri seperti lubang kosong yang berbentuk bulat yang terjadi karena adanya penimbunan lemak. Faktor penyebab vakuolisis adalah penumpukan bahan toksik, kekurangan oksigen atau kelebihan konsumsi lemak. Bila vakuolisis ini tidak hilang maka dapat mengganggu proses metabolisme sel yang lebih parah dan berakibat pada lisisnya sel [9].

Berdasarkan hasil skoring kerusakan jaringan hemoragi dapat disimpulkan bahwa semakin tinggi dosis pengobatan maka semakin kecil kerusakan degenerasi hialin pada histopatologi otot ikan lele (Clarias sp.). Seperti pernyataan [10], adanya hemoragi dapat disebabkan oleh kerusakan endotel kapiler akibat agen infeksi yang beredar di pembuluh darah. Ketika terjadi kerusakan pada pembuluh darah akibat eksotoksin, maka darah akan keluar dari pembuluh darah dan terjadilah hemoragi pada permukaan tubuh. Efek eksotoksin yang berkelanjutan akan menyebabkan semakin banyak sel-sel pada jaringan otot mati, sehingga akan nampak gejala klinis berupa nekrosis pada permukaan tubuh [11].

Hemoragi (pendarahan) adalah kondisi yang ditandai dengan keluarnya darah dari dalam vaskula akibat dari kerusakan dinding vaskula. Kebocoran dinding ada dua macam melalui kerobekan (per reksis) dan melalui perenggangan jarak antara sel-sel endotel vaskula (per diapedisis). Hemoragi per diapedisis umumnya tejadi pada pembuluh kapiler. Adanya hemoragi dapat disebabkan oleh kerusakan endotel kapiler akibat agen infeksi yang beredar di pembuluh darah [10]. Ketika terjadi kerusakan pada pembuluh darah akibat eksotoksin, maka darah akan keluar dari pembuluh darah dan terjadilah hemoragi pada permukaan tubuh. Efek eksotoksin yang berkelanjutan akan menyebabkan semakin banyak sel-sel pada jaringan otot mati, sehingga akan nampak gejala klinis berupa nekrosis pada permukaan tubuh [11]. 


\section{KESIMPULAN}

Berdasarkan hasil penelitian dapat disimpulkan bahwa hasil pengobatan dengan antibiotik oxytetracycline memberikan pengaruh terhadap gambaran histopatologi otot ikan lele (Clarias sp.). Dari hasil penelitian menggunakan perbedaan dosis $\mathrm{A}$ (15 ppm), B (30 ppm), dan C (45 ppm) yang terbaik dalam pengobatan ikan lele dilihat dari perbaikan jaringan otot yakni pada dosis $\mathrm{C}$ (45 ppm), karena pada dosis $45 \mathrm{ppm}$ dapat mempercepat pemulihan jaringan otot ikan lele, nilai skoring kerusakan paling kecil, dan struktur mengarah pada jaringan normal. Dan bakteri Edwardsiella tarda kepadatan $10^{7}$ $\mathrm{CFU} / \mathrm{ml} \quad(\mathrm{K}(+))$ yang digunakan sebagai pembanding hasil histopatologi otot memberikan pengaruh terhadap histopatologi otot ikan lele (Clarias sp.). Bentuk kerusakan jaringan otot ikan lele yang disebabkan oleh infeksi bakteri $E$. tarda yang telah diamati yaitu edema, nekrosis, vakuolisasi dan hemoragi.

\section{UCAPAN TERIMA KASIH}

Ucapan terima kasih kami sampaikan kepada: Universitas Brawijaya dan Direktorat Riset dan Pengabdian Masyarakat, Direkrorat Jendral Penguatan Riset dan Pengembangan, Kementrian Riset, Teknologi, dan Pendidikan Tinggi Sesuai dengan Kontrak Penelitian Nomor: 054/SP2H/LT/DRPM/2018.

\section{DAFTAR PUSTAKA}

[1] Hastuti, S. dan Subandiyono, "Performa produksi lele dumbo (Clarias Gariepinus, Burch) yang dipelihara dengan tenologi biofloc", Jurnal Saintek Perikanan. 10(1): 37-42, 2014.

[2] Andayani, S., H. Suprastyani, G.D.A. Gumala, U. Oktafa, N.M. Fatikah, M. Wahyudi, A. Farida, dan R. Pratama, "Pengaruh pemberian bakteri Lactobacillus plantarum terhadap histopatologi dan hematologi ikan patin jambal (Pangasius djambal) yang diinfeksi bakteri Edwarsiella tarda", Journal of Fisheries and Marine Science. 1(4): 31-38, 2017.
[3] Susanti W., A. Indrawati dan F.H. Pasaribu, "Kajian patogenisitas bakteri Edwardsiella ictaluri pada ikan patin Pangasionodon hypophthalmus", Jurnal Akuakultur Indonesia. 15(2): 99-107, 2016.

[4] Fikar. M., S. Amanu, S.R.T. Simanjuntak dan M.A. Yudistra, "Deteksi Edwardsiella Ictaluri pada ikan dengan metode co-agglutination test", Jurnal Sain Veteriner. 33(2): 222-227, 2015.

[5] Narwiyani S. dan Kurniasih, "Phylogenetic tree dari empat isolat Edwardsiella tarda di Indonesia", Biota. 16(2): 348-353, 2011.

[6] Herawati, L., P.R. Noviyandri dan A.I. Nasution, "Pengaruh Ekstrak Buah Timun Suri (Cucumis sativus L.) sebagai Antibakteri Alami dalam Menghambat Pertumbuhan Enterococcus faecalis", Journal Caninus Denstistry. 3(2): 111116. 2017.

[7] Jasmanidar, Y., "Penggunaan Ekstrak Gracilaria verrucosa untuk Meningkatkan Sistem Ketahanan Udang Vaname (Litopenaeus vannamei)", Tesis. Institut Pertanian Bogor, Bogor, Indonesia, 2009.

[8] Putri A.M., S.B. Prayitno dan Sarjito, "Perendaman berbagai dosis ekstrak daun bakau (Rhizophora apiculata) untuk pengobatan kepiting bakau (Scylla serrata) yang diinfeksi bakteri Vibrio harveyi", Journal of Aquaculture Management and Technology. 4(4): 141 - 149, 2015.

[9] Kartika, E, "Ektoparasit dan struktur jaringan kulit, hati, ginjal, dan insang pada ikan lele dumbo (C. gariepinus) yang terserang penyakit kuning", Universitas Diponegoro. Semarang. 50 hlm, 2010.

[10] Susanti W., A. Indrawati dan F.H. Pasaribu, "Kajian patogenisitas bakteri Edwardsiella ictaluri pada ikan patin Pangasionodon hypophthalmus", Jurnal 
Akuakultur Indonesia. 15(2): 99-107, 2016.

[11] Dianti L., S.B. Prayitno dan R.W. Ariyati, "Ketahanan nonspesifik ikan mas (Cyprinus carpio) yang direndam ekstrak daun jeruju (Acanthus ilicifolius) terhadap infeksi bakteri Aeromonas hydrophila", Journal of Aquaculture Management and Technology. 2(4): 6371, 2013. 